\title{
Is a Human CD8 T-Cell Vaccine Possible, and if So, What Would It Take?
}

\section{Could a CD8 ${ }^{+}$T-Cell Vaccine Prevent Persistent HIV Infection?}

\author{
Andrew J. McMichael \\ Nuffield Department of Medicine, University of Oxford, Oxford OX3 7FZ, United Kingdom \\ Correspondence: andrew.mcmichael@ndm.ox.ac.uk
}

Vaccines that stimulate $\mathrm{CD} 8^{+} \mathrm{T}$ cells could clear early virus infection or control ongoing infection and prevent disease. This could be valuable to combat human immunodeficiency virus type 1 (HIV-1) where it has not yet been possible to generate broadly reacting neutralizing antibodies with a vaccine. However, HIV-1 vaccines aimed at stimulating $\mathrm{CD}^{+} \mathrm{T}$ cells have had no success. In contrast, a cytomegalovirus vectored simian immunodeficiency virus (SIV) vaccine enabled clearance of early SIV infection. This may open the door to the design of an effective HIV vaccine

\section{GREAT DEBATES}

What are the most interesting topics likely to come up over dinner or drinks with your colleagues? Or, more importantly, what are the topics that don't come up because they are a little too controversial? In Immune Memory and Vaccines: Great Debates, Editors Rafi Ahmed and Shane Crotty have put together a collection of articles on such questions, written by thought leaders in these fields, with the freedom to talk about the issues as they see fit. This short, innovative format aims to bring a fresh perspective by encouraging authors to be opinionated, focus on what is most interesting and current, and avoid restating introductory material covered in many other reviews.

The Editors posed 13 interesting questions critical for our understanding of vaccines and immune memory to a broad group of experts in the field. In each case, several different perspectives are provided. Note that while each author knew that there were additional scientists addressing the same question, they did not know who these authors were, which ensured the independence of the opinions and perspectives expressed in each article. Our hope is that readers enjoy these articles and that they trigger many more conversations on these important topics.

Editors: Shane Crotty and Rafi Ahmed

Additional Perspectives on Immune Memory and Vaccines: Great Debates available at www.cshperspectives.org

Copyright @ 2018 Cold Spring Harbor Laboratory Press; all rights reserved; doi: 10.1101/cshperspect.a029124

Cite this article as Cold Spring Harb Perspect Biol 2018;10:a029124 
$T_{e}^{\text {h }}$ his review will address the question of whether it is possible to design a prophylactic vaccine that stimulates protective $\mathrm{CD}^{+} \mathrm{T}$ cells that will control or eradicate infection with a virus that routinely establishes persistent infection. It focuses on human immunodeficiency virus (HIV) vaccines because this is a particularly challenging vaccine problem, of which it has not yet been possible to find a vaccine that can stimulate neutralizing antibodies reactive with enough virus variants to be protective. This raises the question of whether a vaccine that stimulates protective broadly reactive $\mathrm{CD}^{+} \mathrm{T}$ cells would be a possible alternative, or whether a complementing combination of a $\mathrm{CD}^{+} \mathrm{T}$ cell-inducing vaccine and a partially protective antibody-inducing vaccine might offer the most likely route to an effective prophylactic vaccine.

\section{RATIONALE}

There are many examples in experimental animal models where vaccine-induced $\mathrm{CD}^{+} \mathrm{T}$ cells protect against virus infections. These include lymphocytic choriomeningitis virus (LCMV), influenza virus, and respiratory syncytial virus (Yap and Ada 1978; Webster and Askonas 1980; Bachmann et al. 1997; Flynn et al. 1998). Not surprisingly, $\mathrm{CD}^{+}{ }^{+} \mathrm{T}$ cells do not prevent infection, because normally they can only recognize and respond to infected cells, but they can effect rapid virus clearance. $\mathrm{CD} 8^{+} \mathrm{T}$ cells can also prevent long-term persistence of LCMV in mice (Bachmann et al. 1997) and hepatitis C virus in chimpanzees (Folgori et al. 2006), but HIV poses a greater challenge.

In humans, there is strong evidence for a role for $\mathrm{CD}^{+} \mathrm{T}$ cells in the control of early influenza virus infection (McMichael et al. 1983), as well a considerable evidence that $\mathrm{CD} 8^{+} \mathrm{T}$ cells control chronic infection with Epstein-Barr virus (Rickinson and Moss 1997) and cytomegalovirus (CMV), ensuring good health without eliminating the virus (Riddell et al. 1991; Klenerman and Oxenius 2016). In these examples, there is often an additional complementary role for CD4 T cells (Wilkinson et al. 2012) and often a role for natural killer (NK) cells, particularly in controlling herpes virus infections (Lopez-Botet et al. 2004).

There is also extensive evidence that $\mathrm{CD} 8^{+}$ T cells are effective at controlling HIV infection (reviewed in McMichael et al. 2010; Carrington and Walker 2012); however, this control ultimately fails in the absence of antiretroviral drug therapy. The evidence for $\mathrm{CD}^{+} \mathrm{T}$-cell control includes the complementary kinetics of the early $\mathrm{T}$-cell response and viral load, rapid and extensive selection of virus escape mutants, and the strong impact of HLA-1 type on control of virus. Additional evidence comes from the monkey simian immunodeficiency virus (SIV) model system where $\mathrm{CD}^{+} \mathrm{T}$-cell depletion impairs and restoration reestablishes virus control (Jin et al. 1999; Schmitz et al. 1999).

\section{VACCINATION STUDIES}

Demonstration that $\mathrm{CD}^{+} \mathrm{T}$ cells contribute to virus control in people infected with HIV-1 does not necessarily mean that vaccine induction of $\mathrm{CD}^{+} \mathrm{T}$ cells will be beneficial. That demonstration requires vaccination ahead of natural HIV infection, or vaccination followed by challenge with SIV in monkeys. Vaccination in humans has so far been disappointing. Very large-scale, expensive, and time-consuming clinical trials are needed for efficacy studies and only two $\mathrm{CD} 8^{+} \mathrm{T}$ cell vaccines that have so far been tested for efficacy. Both were based on recombinant adenovirus-5 with or without an initial DNA prime. Neither showed evidence of protection (see Table 1). However, that does not necessarily mean that the concept is wrong; the immune responses stimulated might have been inadequate. In contrast, there was a $31 \%$ reduction in HIV infection seen in the RV144 trial where a recombinant canarypox vaccine primed and an envelope protein boosted, but that protection could not be attributed to $\mathrm{CD}^{+} \mathrm{T}$ cells nor to neutralizing antibody (Rerks-Ngarm et al. 2009). Most likely antibody-dependent cell-mediated viral inhibition was associated with the rather short-lived protection seen (Haynes et al. 2012).

The SIV model has yielded more encouraging results. The first attempts at stimulating $\mathrm{CD}^{+} \mathrm{T}$ cells in monkeys used SIV nonenvelope 
Is a Human CD8 T-Cell Vaccine Possible?

Table 1. Efficacy of vaccines in human trials

\begin{tabular}{|c|c|c|c|c|}
\hline $\begin{array}{l}\text { Human } \\
\text { Trial }\end{array}$ & Vaccine & Insert & Efficacy? & References \\
\hline STEP & Adenovirus-5 & $\begin{array}{l}\text { HIV Gag, Pol, } \\
\text { Nef }\end{array}$ & No protection & Buchbinder et al. 2008 \\
\hline HVTN505 & DNA + adenovirus-5 & $\begin{array}{l}\text { Gag, Pol, Nef, } \\
\text { Env }\end{array}$ & No protection & Hammer et al. 2013 \\
\hline RV144 & $\begin{array}{l}\text { Canarypox }+ \text { Env } \\
\text { protein }\end{array}$ & $\begin{array}{l}\text { Gag, Pol, Env + } \\
\text { Env gp120 }\end{array}$ & $\begin{array}{l}\text { 31\% reduction in acquisition } \\
\text { (attributed to non- } \\
\text { neutralizing antibody) }\end{array}$ & Rerks-Ngarm et al. 2009 \\
\hline
\end{tabular}

proteins expressed by plasmid DNA or vectors such as modified vaccinia virus ankara (MVA), adenovirus-5, or vesicular stomatitis virus (VSV). $\mathrm{CD}^{+} \mathrm{T}$-cell responses were generated and there were reduced virus loads after challenge with SHIV89.6P (Rose et al. 2001; Barouch et al. 2002; Amara et al. 2005). That challenge virus (SIV with an HIV envelope) was chosen because it was very aggressive with a rapidly fatal decline in host CD4 T-cell numbers. Paradoxically, SHIV89.6P turned out to be relatively easy to control by any immune response and was misleading therefore. The more natural isolate SIV mac239 was shown to be much more rigorous as a challenge virus (Casimiro et al. 2005). Protection against SIVmac239 offered by the same types of vaccines as above was less impressive, although some control could be obtained (Casimiro et al. 2005; Liu et al. 2009; Martins et al. 2015). These positive SIVmac239 results are not necessarily inconsistent with the failed HIV vaccine trials, because the induced $\mathrm{CD}^{+} \mathrm{T}$-cell responses were much weaker in the human studies (Fig. 1) (Liu et al. 2009; Haynes et al. 2016).

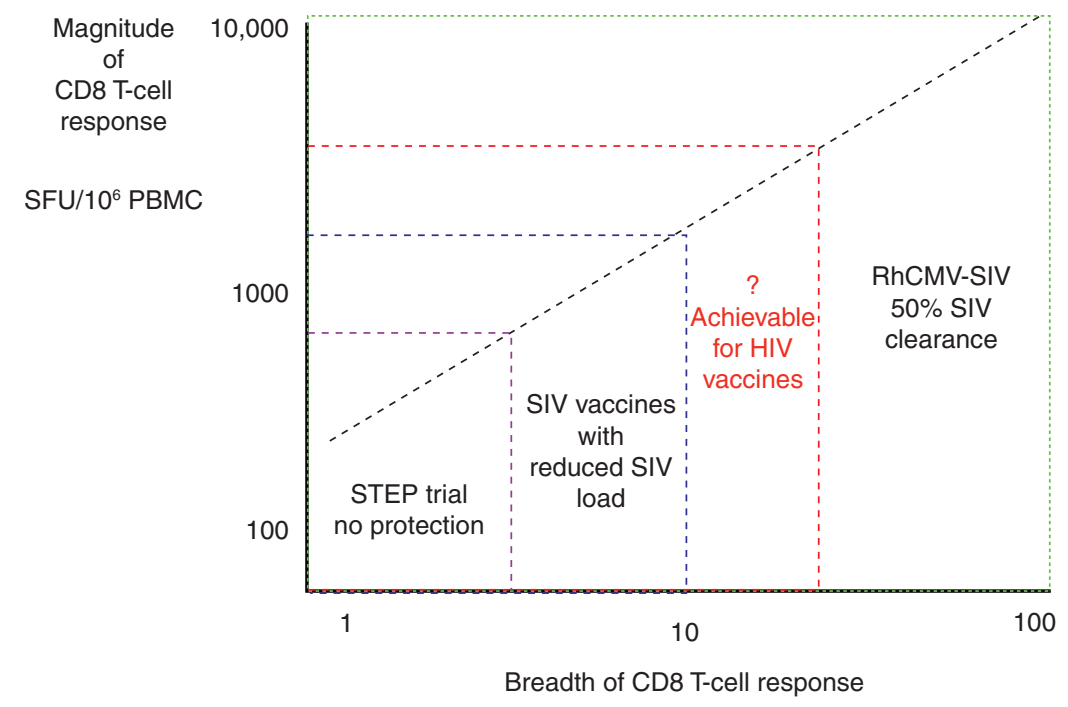

Figure 1. Relationship between magnitude and breadth of $\mathrm{CD}^{+} \mathrm{T}$-cell responses and protection. Plots, based on data, are shown for the STEP human immunodeficiency virus type 1 (HIV-1) vaccine trial, and simian immunodeficiency virus (SIV) mac239-CD8 ${ }^{+} \mathrm{T}$-cell vaccine-challenge studies, where the primary aim was to stimulate $\mathrm{CD} 8^{+} \mathrm{T}$-cell responses. The $y$-axis shows the peak magnitude of the vaccine-stimulated T-cell response as spot forming units (SFU)/million peripheral blood mononuclear cells (PBMCs) in the interferon- $\gamma$ enzyme linked immunospot (ELISPOT) assay and the $x$-axis shows the breadth of the vaccine-induced T-cell responses shown as the number of epitopes the vaccine stimulated. Indicated are the upper limits of each type of T-cell response and the outcome. Further details can be found in Haynes et al. (2016). 
The poor results in the human trials of vaccines that stimulated $\mathrm{CD}^{+} \mathrm{T}$ cells without neutralizing antibody (see Table 1) led to the idea of mixing in an HIV envelope (Env) vaccine so that both $\mathrm{T}$ cells and antibody could be generated. This was the rationale for the RV144 trial in Thailand (Table 1), although that vaccine barely stimulated any $\mathrm{CD} 8^{+}$ $\mathrm{T}$ cells. Similar vaccine combinations in monkeys using an adenovirus-env-gag-pol to prime with an Env protein boost to stimulate both $\mathrm{CD}^{+} \mathrm{T}$ cells, $\mathrm{CD} 4^{+} \mathrm{T}$ cells, and nonneutralizing antibody have given up to $50 \%$ protection from SIV acquisition after six repeated low-dose mucosal SIVmac239 challenges (Barouch et al. 2015). In animals that became infected, virus load was slightly reduced, which could be attributed to the vaccine-induced $\mathrm{CD}^{+} \mathrm{T}$-cell response, in line with earlier studies. If the RV144 trial result is reproducible in current human trials, the virus vector prime plus Env protein boost approach could offer partial protection. However, by testing this type of vaccine in humans exposed to a much higher HIV-1 risk than the original Thai cohort, the small reduction in HIV-1 infection seen in the RV144 trial may be obscured. Whatever the result, such studies are unlikely to answer the question posed here because the $\mathrm{CD} 8^{+} \mathrm{T}$-cell responses are not optimized and there is an antibody component. Furthermore, because the protection in humans and monkeys has only been seen early in infection or with a limited number of SIV challenges, respectively, there is a risk that this approach will not offer broad and long-lasting protection in humans.

Thus, conventional vaccine approaches using recombinant adenoviruses, pox viruses, and/ or DNA have given some encouraging results in monkeys but no protection in humans. The limited protection seen in the RV144 trial could not be attributed to $\mathrm{CD} 8^{+} \mathrm{T}$-cell responses. These results led to a common perception that $\mathrm{CD} 8^{+}$ $\mathrm{T}$ cells would not be useful in a prophylactic vaccine. That view was then challenged by studies using recombinant $\mathrm{CMV}$-vectored vaccines in an SIV model system (Hansen et al. 2009, 2013a).

\section{CMV-VECTORED VACCINE}

The original aim of the CMV-vectored vaccine was to try to get SIV-specific $\mathrm{CD}^{+}{ }^{+} \mathrm{T}$-cell responses similar in magnitude to the very strong anti-CMV CD8 ${ }^{+}$T-cell responses seen in humans chronically infected with human CMV (HCMV) (Hansen et al. 2009). Also it was expected that such $\mathrm{T}$ cells would be of the effector memory phenotype and therefore ready to act on SIV-infected cells with little further differentiation. This was achieved in the first experiments, which showed, unexpectedly, that half of the animals were able to completely clear infection with SIVmac239 when challenged a year after vaccination (Hansen et al. 2009, 2013a). The animals became infected soon after challenge, but they then eradicated virus over 1-6 months. While similar to clearance of an acutely infecting virus such as an influenza virus, this was unprecedented for a lentivirus, which establishes a reservoir of latent provirus infected cells soon after infection.

Hansen et al. (2009) have argued very strongly that this protection was mediated by vaccine-induced $\mathrm{CD}^{+} \mathrm{T}$ cells. Although the animals were immunized with a recombinant rhesus monkey cytomegalovirus strain 68-1 (RhCMV68-1) that included all of SIV except Vif, there was no SIV-specific-neutralizing antibody generated and only low levels of non-neutralizing antibodies (Hansen et al. 2009). This makes any form of antibody-mediated protection unlikely. Furthermore, the nature of the protection seen was very different from that seen in the RV144 trial (Haynes et al. 2012) and in similar studies in monkeys (Barouch et al. 2015), where there was reduced acquisition but no evidence of viral clearance once infection occurred. In contrast, the CMV-based vaccine induced very strong $\mathrm{CD}^{+} \mathrm{T}$-cell responses and the pattern of virus elimination over a few weeks was very similar to $\mathrm{CD}^{+}{ }^{+} \mathrm{T}$-cell-mediated clearance of many acutely infecting viruses (Yap and Ada 1978; Flynn et al. 1998). Although T cells and NK cells often work together to clear acute virus infections, in this case a dominant role for innate immune responses is unlikely because all of the vaccinated animals were already infected 
with natural RhCMV. Although NK cells are activated by acute CMV infection, they are unlikely to be further enhanced by "chronic" superinfection with the vaccine. Therefore, the vaccine stimulated $\mathrm{CD}^{+} \mathrm{T}$-cell responses were almost certainly responsible for clearance of SIV after challenge.

If this interpretation is correct, it raises the question of why this particular T-cell response could eradicate early SIV infection in $>50 \%$ of SIV-challenged animals, whereas T cells stimulated by SIV itself or by other vaccines could not. There are several possible explanations:

1. The T-cell responses were of much greater magnitude and/or breadth than previous vaccine- or SIV-induced responses.

2. The function and state of activation, or preparedness, of the $\mathrm{T}$ cells was more effective than with previous vaccines or in acute SIV infection.

3. Other qualities of the T cells were different.

These hypotheses are not mutually exclusive. The total magnitude of the $\mathrm{T}$-cell responses was not much higher than with previous vaccines (Hansen et al. 2009), making this the least likely of these explanations. On the other hand, the T-cell responses were extraordinarily broad (Hansen et al. 2013b). Epitopes recognized by the $\mathrm{CD}^{+} \mathrm{T}$ cells occurred on average every 30 amino acids of the SIV proteome, so $>100$ epitopes were recognized by each animal in total (Hansen et al. 2016). This contrasts with 10-30 for previous vaccine approaches or after SIV infection. Responses in HIV-infected humans are even narrower, probably because there are fewer classical HLA class I loci in humans than in rhesus macaques (Wiseman et al. 2013). Narrowly immunodominant $\mathrm{T}$-cell responses, seen in acute SIV/HIV infection and with most vaccines, rapidly select virus escape mutants and compromise control of virus (Liu et al. 2013). Here, the extremely broad T-cell responses, which lacked clear immunodominance hierarchies, could make it impossible for the virus to escape. So the great breadth of the response could be very important to protection.
The $\mathrm{CD}^{+} \mathrm{T}$ cells that expanded after RhCMV68-1 vaccination were activated effector memory cells, continuously stimulated by the replicating virus (Hansen et al. 2009). This contrasts with the resting memory $\mathrm{T}$ cells generated following immunization with nonpersisting vaccine vectors. A need for activated effector memory $\mathrm{T}$ cell protection is reminiscent of the finding that murine $\mathrm{CD}^{+}{ }^{+} \mathrm{T}$-cell-mediated protection against LCMV required T cells recently restimulated by virus (Bachmann et al. 1997).

Finally, the T-cell responses elicited by the RhCMV68.1 vector were very unusual in quality. Two-thirds of the $\mathrm{CD}^{+} \mathrm{T}$ cells were restricted by the major histocompatibility complex class II (MHC-II) and one-third by the nonclassical MHC-E molecules (Hansen et al. 2013b, 2016). These unusual T-cell responses might be protective because these MHC molecules were highly permissive in the peptides they presented in Hansen et al. (2013b, 2016), resulting in extreme response breadth. MHC-II- and MHC-E-specific $\mathrm{CD}^{+}{ }^{+} \mathrm{T}$ cells might also be particularly effective in cells that have down-regulated classical MHC class I proteins. Furthermore, the atypical $\mathrm{T}$ cells might be particularly effective if the long-lived latently SIV-infected cells in the virus reservoir, such as $\mathrm{CD}^{+} \mathrm{T}$ follicular helper $\left(\mathrm{T}_{\mathrm{FH}}\right)$ cells in the lymphoid follicles (Fukazawa et al. 2015), express MHCII or MHC-E. The latter seems more likely because MHC-II expression is enhanced on T-cell activation, as are SIV/HIV replication, so is unlikely to define latently infected T cells. In contrast, there is evidence in mice and humans that $\mathrm{T}_{\mathrm{FH}}$ cells can be regulated in lymphoid follicles by lytic and nonlytic $\mathrm{CD}{ }^{+} \mathrm{T}$ cells restricted by H2-Qa1 (the H-2 HLA-E equivalent) (Kim et al. 2010) or HLA-E, respectively (Jiang et al. 2010).

If the unusual nature of these protective $\mathrm{T}$ cell responses is important for protection, the findings may also provide an explanation for why $45 \%$ of vaccinated monkeys were not protected. Hansen et al. (2016) have identified several RhCMV68-1 genes that are essential to the generation of the MHC-II- and MHC-E-restricted $\mathrm{CD}^{+}{ }^{+} \mathrm{T}$-cell responses. For SIV-infected cells to be recognized by these $\mathrm{CD} 8^{+} \mathrm{T}$ cells, they must display MHC-II- or MHC-E-containing 


\section{A.J. McMichael}

virus peptides at their surface. $\mathrm{CD}^{+} \mathrm{T}$ cells can recognize target cells that express less than 10 peptide-MHC complexes on the surface (Purbhoo et al. 2004). In contrast, priming a T-cell response requires much more peptide on the antigen-presenting cells (Met et al. 2003). Thus, while SIV lacks the genetic mechanisms that RhCMV68-1 uses to favor the binding of epitope peptides to MHC-E and prime these unusual responses, it can put enough peptides into MHC-E to generate targets (Fig. 2). However, SIV-infected cells in some animals may present better than others, and only the former would be protected. There is more polymorphism of MHC-E in monkeys compared to humans and some peptides or allotypes may present better than others. This hypothesis and alternative hypotheses that the lack of protection is the result of some other as-yet-undetermined property of the vaccine-induced T cells need to be tested.

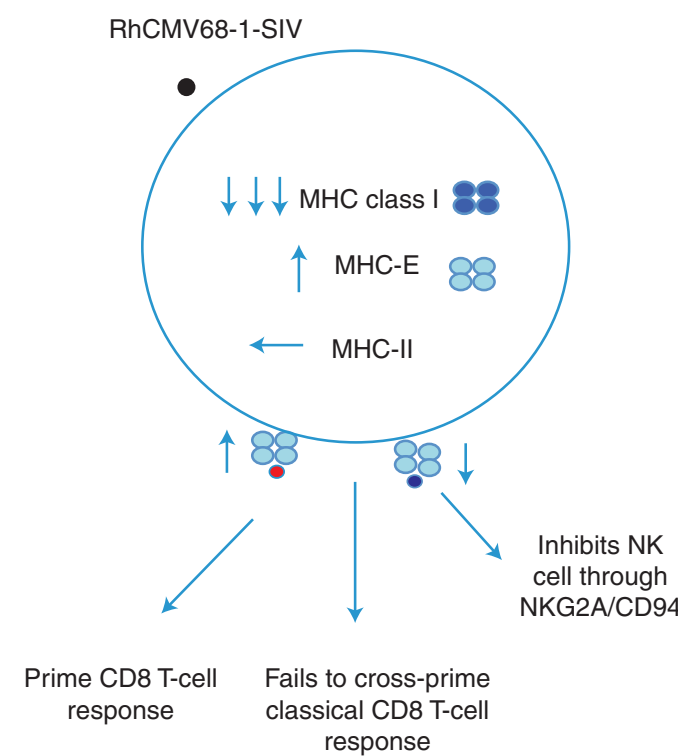

- MHC-E binding SIV peptides

- MHC-E binding signal peptide VMAPRTLVL

- Classical SIV epitope peptides

Figure 2. How RhCMV68-1-SIV and simian immunodeficiency virus (SIV) differ in presenting SIV peptides to $\mathrm{CD}^{+} \mathrm{T}$ cells. The diagram shows a cell (of unknown type) infected by the tropism restricted RhCMV68-1-SIV on the left and an activated $\mathrm{CD} 4^{+} \mathrm{T}$-cell infected with SIV on the right. The relative levels of major histocompatibility complex (MHC)-E, classical MHC-I, and MHC-II are shown together with the epitopes expressed on the cell surface that may lead to priming of a $\mathrm{CD} 8^{+} \mathrm{T}$-cell response or make the cell a target for $\mathrm{CD} 9^{+} \mathrm{T}$ cells (based on McMichael and Picker 2017). NK, Natural killer. 
Is a Human CD8 T-Cell Vaccine Possible?

or HLA-II. The simplest approach would be to use an HCMV vector that is equivalent to RhMV68-1. However, RhCMV68-1 has unusual features that are critical to its ability to prime these responses and protect (Hansen et al. 2013b, 2016), in particular, the loss of the RhCMV equivalents to the HCMV UL128 and UL131 genes that contribute to virus tropism, and the presence of the equivalent of HCMV US11, which down-regulates classical MHC class I molecules. There may be additional genes or deletions that are critical, and these need to be identified to design an HCMV that elicits the same type of T-cell responses.

The use of HCMV as a vaccine may carry some risk because $\mathrm{CMV}$ can be a pathogen (Griffiths et al. 2015). HCMV infection downregulates antigen presentation so it is possible for HMCV-infected individuals to be superinfected. Therefore, volunteers from the $>50 \%$ of humans who are naturally chronically infected with HCMV would be tested first. This will eliminate the risk of introducing CMV for the first time, but the modifications in HCMV needed to make it equivalent to RhCMV68-1 may cause problems. Potential issues might be circumvented by the insertion of suicide genes into the vaccine HCMV vector so that a drug treatment could remove the vaccine virus after response priming if needed.

An alternative approach will be to use other vectors or DNA plasmids to elicit the desired T-cell responses (e.g., HLA-E-restricted responses). It is known, for instance, that Mycobacterium tuberculosis (Mtb) and bacille Calmette-Guérin (BCG) naturally prime HLAE-restricted T-cell responses in humans (Joosten et al. 2010). This appears to be dependent on antigen processing in, and $\mathrm{T}$-cell priming by, Mtb-infected macrophages (Grotzke et al. 2009). Therefore, a BCG vector is attractive, although it has the disadvantage that the recombinant gene or genes are only a tiny part of the whole Mtb genome and so it may not be efficient in stimulating $\mathrm{T}$-cell responses specific for the inserted HIV gene. However, once more is known about how these responses are primed it may be possible to use other approaches.

\section{CONCLUDING REMARKS}

Conventional approaches to a $\mathrm{CD} 8^{+} \mathrm{T}$-cell-stimulating vaccine have so far failed to generate $\mathrm{T}$ cell responses that are capable of protecting and clearing SIV or HIV infection. In contrast, an RhCMV-based SIV vaccine does this in half the monkeys subsequently challenged with SIV. It is highly likely that $\mathrm{CD}^{+} \mathrm{T}$ cells are responsible for that protection. Those $\mathrm{CD}^{+} \mathrm{T}$ cells have unusual features, being restricted by $\mathrm{MHC}$ class II or MHC-E. The exceptional breadth of these effector memory $\mathrm{T}$-cell responses likely contributes to their effectiveness, but their target specificity could also be critical. The MHC-Erather than the MHC-II-restricted T cells seem most likely to be responsible for the SIV control, but this needs to be shown experimentally. Then these findings will need translating into an HIV vaccine that is effective. Because not all monkeys are protected by the RhCMV vaccine, it is possible that incomplete protection could also be a problem in humans. Even so, this is the most exciting and promising of all HIV vaccine approaches at present. Once fully understood, this type of vaccine could also have potential in several other contexts, including infections and cancer.

\section{COMPETING INTEREST STATEMENT}

The author has no conflicts of interest.

\section{ACKNOWLEDGMENTS}

I thank Persephone Borrow and Louis Picker for many discussions on the topics reviewed here. A.J.M. is funded by the National Institutes of Health (NIH) Center for HIV AIDS Vaccine Immunology Immunogen Discovery Grant No. UM1 AI 00645-02 and the Medical Research Council Programme Grant MR/K012037/2.

\section{REFERENCES}

Amara RR, Patel K, Niedziela G, Nigam P, Sharma S, Staprans SI, Montefiori DC, Chenareddi L, Herndon JG, Robinson HL, et al. 2005. A combination DNA and attenuated simian immunodeficiency virus vaccine strategy provides enhanced protection from simian/human 
A.J. McMichael

immunodeficiency virus-induced disease. J Virol 79: 15356-15367.

Bachmann MF, Kundig TM, Hengartner H, Zinkernagel RM. 1997. Protection against immunopathological consequences of a viral infection by activated but not resting cytotoxic T cells: $\mathrm{T}$ cell memory without "memory $\mathrm{T}$ cells"? Proc Natl Acad Sci 94: 640-645.

Barouch DH, Kunstman J, Kuroda MJ, Schmitz JE, Santra S, Peyerl FW, Krivulka GR, Beaudry K, Lifton MA, Gorgone DA, et al. 2002. Eventual AIDS vaccine failure in a rhesus monkey by viral escape from cytotoxic T lymphocytes. Nature 415: 335-339.

Barouch DH, Alter G, Broge T, Linde C, Ackerman ME, Brown EP, Borducchi EN, Smith KM, Nkolola JP, Liu J, et al. 2015. Protective efficacy of adenovirus/protein vaccines against SIV challenges in rhesus monkeys. Science 349: 320-324.

Buchbinder SP, Mehrotra DV, Duerr A, Fitzgerald DW, Mogg R, Li D, Gilbert PB, Lama JR, Marmor M, Del Rio C, et al. 2008. Efficacy assessment of a cell-mediated immunity HIV-1 vaccine (the Step Study): A doubleblind, randomised, placebo-controlled, test-of-concept trial. Lancet 372: 1881-1893.

Carrington M, Walker BD. 2012. Immunogenetics of spontaneous control of HIV. Annu Rev Med 63: 131-145.

Casimiro DR, Wang F, Schleif WA, Liang X, Zhang ZQ, Tobery TW, Davies ME, McDermott AB, O'Connor DH, Fridman A, et al. 2005. Attenuation of simian immunodeficiency virus SIVmac239 infection by prophylactic immunization with DNA and recombinant adenoviral vaccine vectors expressing Gag. J Virol 79: 1554715555.

Flynn KJ, Belz GT, Altman JD, Ahmed R, Woodland DL, Doherty PC. 1998. Virus-specific CD $8^{+}$T cells in primary and secondary influenza pneumonia. Immunity 8: 683691.

Folgori A, Capone S, Ruggeri L, Meola A, Sporeno E, Ercole BB, Pezzanera M, Tafi R, Arcuri M, Fattori E, et al. 2006. A T-cell HCV vaccine eliciting effective immunity against heterologous virus challenge in chimpanzees. Nat Med 12: 190-197.

Fukazawa Y, Lum R, Okoye AA, Park H, Matsuda K, Bae JY, Hagen SI, Shoemaker R, Deleage C, Lucero C, et al. 2015. $B$ cell follicle sanctuary permits persistent productive simian immunodeficiency virus infection in elite controllers. Nat Med 21: 132-139.

Griffiths P, Baraniak I, Reeves M. 2015. The pathogenesis of human cytomegalovirus. J Pathol 235: 288-297.

Grotzke JE, Harriff MJ, Siler AC, Nolt D, Delepine J, Lewinsohn DA, Lewinsohn DM. 2009. The Mycobacterium tuberculosis phagosome is a HLA-I processing competent organelle. PLoS Pathog 5: e1000374.

Haigwood NL, Walker CM. 2011. Commissioned paper: Comparison of immunity to pathogens in humans, chimpanzees, and macaques. In Chimpanzees in biomedical and behavioral research: Assessing the necessity (ed. Altevogt PD, et al.). National Academies Press, Washington, D.C.

Hammer SM, Sobieszczyk ME, Janes H, Karuna ST, Mulligan MJ, Grove D, Koblin BA, Buchbinder SP, Keefer MC, Tomaras GD, et al. 2013. Efficacy trial of a DNA/rAd5 HIV-1 preventive vaccine. N Engl J Med 369: 2083-2092.
Hansen SG, Vieville C, Whizin N, Coyne-Johnson L, Siess DC, Drummond DD, Legasse AW, Axthelm MK, Oswald K, Trubey CM, et al. 2009. Effector memory T cell responses are associated with protection of rhesus monkeys from mucosal simian immunodeficiency virus challenge. Nat Med 15: 293-299.

Hansen SG, Piatak M Jr, Ventura AB, Hughes CM, Gilbride RM, Ford JC, Oswald K, Shoemaker R, Li Y, Lewis MS, et al. 2013a. Immune clearance of highly pathogenic SIV infection. Nature 502: 100-104.

Hansen SG, Sacha JB, Hughes CM, Ford JC, Burwitz BJ, Scholz I, Gilbride RM, Lewis MS, Gilliam AN, Ventura $\mathrm{AB}$, et al. 2013b. Cytomegalovirus vectors violate $\mathrm{CD} 8^{+} \mathrm{T}$ cell epitope recognition paradigms. Science 340: 1237874.

Hansen SG, Wu HL, Burwitz BJ, Hughes CM, Hammond KB, Ventura AB, Reed JS, Gilbride RM, Ainslie E, Morrow DW, et al. 2016. Broadly targeted $\mathrm{CD} 8^{+} \mathrm{T}$ cell responses restricted by major histocompatibility complex E. Science 351: 714-720.

Haynes BF, Gilbert PB, McElrath MJ, Zolla-Pazner S, Tomaras GD, Alam SM, Evans DT, Montefiori DC, Karnasuta C, Sutthent R, et al. 2012. Immune-correlates analysis of an HIV-1 vaccine efficacy trial. N Engl J Med 366: 12751286.

Haynes BF, Shaw GM, Korber B, Kelsoe G, Sodroski J, Hahn BH, Borrow P, McMichael AJ. 2016. HIV-host interactions: Implications for vaccine design. Cell Host Microbe 19: 292-303.

Jiang H, Canfield SM, Gallagher MP, Jiang HH, Jiang Y, Zheng Z, Chess L. 2010. HLA-E-restricted regulatory $\mathrm{CD}^{+} \mathrm{T}$ cells are involved in development and control of human autoimmune type 1 diabetes. J Clin Invest 120: $3641-3650$.

Jin X, Bauer DE, Tuttleton SE, Lewin S, Gettie A, Blanchard J, Irwin CE, Safrit JT, Mittler J, Weinberger L, et al. 1999. Dramatic rise in plasma viremia after $\mathrm{CD}^{+} \mathrm{T}$ cell depletion in simian immunodeficiency virus-infected macaques. J Exp Med 189: 991-998.

Joosten SA, van Meijgaarden KE, van Weeren PC, Kazi F, Geluk A, Savage ND, Drijfhout JW, Flower DR, Hanekom WA, Klein MR, et al. 2010. Mycobacterium tuberculosis peptides presented by HLA-E molecules are targets for human CD8 T cells with cytotoxic as well as regulatory activity. PLoS Pathog 6: e1000782.

Kim HJ, Verbinnen B, Tang X, Lu L, Cantor H. 2010. Inhibition of follicular T-helper cells by $\mathrm{CD}^{+}$regulatory $\mathrm{T}$ cells is essential for self tolerance. Nature 467: 328-332.

Klenerman P, Oxenius A. 2016. T cell responses to cytomegalovirus. Nat Rev Immunol 16: 367-377.

Liu J, O’Brien KL, Lynch DM, Simmons NL, La Porte A, Riggs AM, Abbink P, Coffey RT, Grandpre LE, Seaman MS, et al. 2009. Immune control of an SIV challenge by a T-cell-based vaccine in rhesus monkeys. Nature 457: 8791.

Liu MK, Hawkins N, Ritchie AJ, Ganusov VV, Whale V, Brackenridge S, Li H, Pavlicek JW, Cai F, Rose-Abrahams $\mathrm{M}$, et al. 2013. Vertical T cell immunodominance and epitope entropy determine HIV-1 escape. J Clin Invest 123: 380-393.

Lopez-Botet M, Angulo A, Guma M. 2004. Natural killer cell receptors for major histocompatibility complex class I 
and related molecules in cytomegalovirus infection. Tissue Antigens 63: 195-203.

Martins MA, Tully DC, Cruz MA, Power KA, Veloso de Santana MG, Bean DJ, Ogilvie CB, Gadgil R, Lima NS, Magnani DM, et al. 2015. Vaccine-induced simian immunodeficiency virus-specific $\mathrm{CD}^{+} \mathrm{T}$-cell responses focused on a single Nef epitope select for escape variants shortly after infection. J Virol 89: 10802-10820.

McMichael AJ, Picker LJ. 2017. Unusual antigen presentation offers new insight into HIV vaccine design. Current Opin Immunol 46: 15-81.

McMichael AJ, Gotch FM, Noble GR, Beare PA. 1983. Cytotoxic T-cell immunity to influenza. N Engl J Med 309: 13-17.

McMichael AJ, Borrow P, Tomaras GD, Goonetilleke N, Haynes BF. 2010. The immune response during acute HIV-1 infection: Clues for vaccine development. Nat Rev Immunol 10: 11-23.

Met O, Buus S, Claesson MH. 2003. Peptide-loaded dendritic cells prime and activate MHC-class I-restricted T cells more efficiently than protein-loaded cross-presenting DC. Cell Immunol 222: 126-133.

Powers C, Fruh K. 2008. Rhesus CMV: An emerging animal model for human CMV. Med Microbiol Immunol 197: 109-115.

Purbhoo MA, Irvine DJ, Huppa JB, Davis MM. 2004. T cell killing does not require the formation of a stable mature immunological synapse. Nat Immunol 5: 524-530.

Rerks-Ngarm S, Pitisuttithum P, Nitayaphan S, Kaewkungwal J, Chiu J, Paris R, Premsri N, Namwat C, de Souza M, Adams E, et al. 2009. Vaccination with ALVAC and AIDSVAX to prevent HIV-1 infection in Thailand. N Engl J Med 361: 2209-2220.
Rickinson AB, Moss DJ. 1997. Human cytotoxic T lymphocyte responses to Epstein-Barr virus infection. Annu Rev Immunol 15: 405-431.

Riddell SR, Reusser P, Greenberg PD. 1991. Cytotoxic T cells specific for cytomegalovirus: A potential therapy for immunocompromised patients. Rev Infect Dis 13: S966S973.

Rose NF, Marx PA, Luckay A, Nixon DF, Moretto WJ, Donahoe SM, Montefiori D, Roberts A, Buonocore L, Rose JK. 2001. An effective AIDS vaccine based on live attenuated vesicular stomatitis virus recombinants. Cell 106: 539-549.

Schmitz JE, Kuroda MJ, Santra S, Sasseville VG, Simon MA Lifton MA, Racz P, Tenner-Racz K, Dalesandro M, Scallon BJ, et al. 1999. Control of viremia in simian immunodeficiency virus infection by $\mathrm{CD}^{+}$lymphocytes. Science 283: 857-860.

Sharp PM, Hahn BH. 2011. Origins of HIV and the AIDS pandemic. Cold Spring Harb Perspect Med 1: a006841.

Webster RG, Askonas BA. 1980. Cross-protection and crossreactive cytotoxic $\mathrm{T}$ cells induced by influenza virus vaccines in mice. Eur J Immunol 10: 396-401.

Wilkinson TM, Li CK, Chui CS, Huang AK, Perkins M, Liebner JC, Lambkin-Williams R, Gilbert A, Oxford J, Nicholas B, et al. 2012. Preexisting influenza-specific $\mathrm{CD}^{+} \mathrm{T}$ cells correlate with disease protection against influenza challenge in humans. Nat Med 18: 274-280.

Wiseman RW, Karl JA, Bohn PS, Nimityongskul FA, Starrett GJ, O'Connor DH. 2013. Haplessly hoping: Macaque major histocompatibility complex made easy. ILAR J 54: 196-210.

Yap KL, Ada GL. 1978. The recovery of mice from influenza virus infection: Adoptive transfer of immunity with immune T lymphocytes. Scand J Immunol 7: 389-397. 


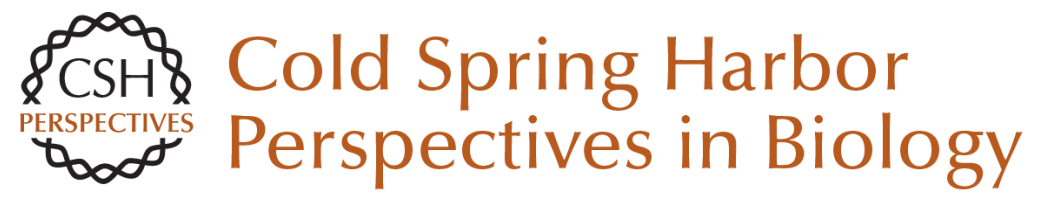

\title{
Is a Human CD8 T-Cell Vaccine Possible, and if So, What Would It Take?: Could a CD8+ T-Cell Vaccine Prevent Persistent HIV Infection?
}

\author{
Andrew J. McMichael
}

Cold Spring Harb Perspect Biol 2018; doi: 10.1101/cshperspect.a029124 originally published online December 18, 2017

Subject Collection Immune Memory and Vaccines: Great Debates

Is There Natural Killer Cell Memory and Can It Be Harnessed by Vaccination?: Can Natural Killer and CD8 T Cells Switch Jobs?

Christine A. Biron and Marcus Altfeld

Is There Natural Killer Cell Memory and Can It Be Harnessed by Vaccination?: Vaccination Strategies Based on NK Cell and ILC Memory Megan A. Cooper, Todd A. Fehniger and Marco Colonna

Is It Possible to Develop Cancer Vaccines to Neoantigens, What Are the Major Challenges, and How Can These Be Overcome?: Neoantigens as Vaccine Targets for Cancer Haydn T. Kissick

Is It Possible to Develop Cancer Vaccines to Neoantigens, What Are the Major Challenges, and How Can These Be Overcome?: Neoantigens: Nothing New in Spite of the Name

Olivera J. Finn and Hans-Georg Rammensee

Which Dengue Vaccine Approach Is the Most Promising, and Should We Be Concerned about Enhanced Disease after Vaccination?: The Challenges of a Dengue Vaccine

Gavin Screaton and Juthathip Mongkolsapaya
Is There Natural Killer Cell Memory and Can It Be Harnessed by Vaccination?: NK Cell Memory and Immunization Strategies against Infectious Diseases and Cancer Joseph C. Sun and Lewis L. Lanier

Is There Natural Killer Cell Memory and Can It Be Harnessed by Vaccination?: Natural Killer Cells in Vaccination

Harold R. Neely, Irina B. Mazo, Carmen Gerlach, et al.

Is It Possible to Develop Cancer Vaccines to Neoantigens, What Are the Major Challenges, and How Can These Be Overcome?: Targeting the Right Antigens in the Right Patients Stephen P. Schoenberger

Which Dengue Vaccine Approach Is the Most Promising, and Should We Be Concerned about Enhanced Disease after Vaccination?: There Is Only One True Winner Scott B. Halstead

Which Dengue Vaccine Approach Is the Most Promising, and Should We Be Concerned about Enhanced Disease after Vaccination?: Questions Raised by the Development and Implementation of Dengue Vaccines: Example of the Sanofi Pasteur Tetravalent Dengue Vaccine Bruno Guy

For additional articles in this collection, see http://cshperspectives.cshlp.org/cgi/collection/

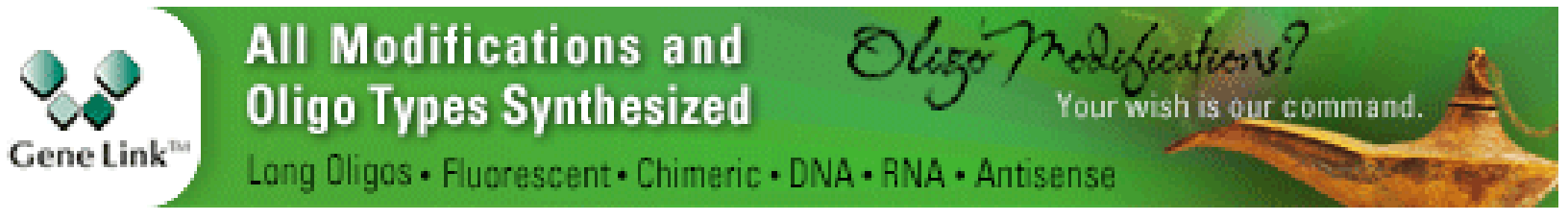


Which Dengue Vaccine Approach Is the Most Promising, and Should We Be Concerned about Enhanced Disease after Vaccination?: The Path to a Dengue Vaccine: Learning from Human Natural Dengue Infection Studies and Vaccine Trials Aravinda M. de Silva and Eva Harris

Is It Possible to Develop a "Universal" Influenza Virus Vaccine?: Potential for a Universal Influenza Vaccine

James E. Crowe, Jr.

Is It Possible to Develop a "Universal" Influenza Virus Vaccine?: Outflanking Antibody Immunodominance on the Road to Universal Influenza Vaccination

Davide Angeletti and Jonathan W. Yewdell
Which Dengue Vaccine Approach Is the Most Promising, and Should We Be Concerned about Enhanced Disease after Vaccination?: The Risks of Incomplete Immunity to Dengue Virus Revealed by Vaccination

Stephen S. Whitehead and Kanta Subbarao

Is It Possible to Develop a "Universal" Influenza Virus Vaccine?: Immunogenetic Considerations Underlying B-Cell Biology in the Development of a Pan-Subtype Influenza A Vaccine Targeting the Hemagglutinin Stem

Sarah F. Andrews, Barney S. Graham, John R. Mascola, et al.

Is It Possible to Develop a "Universal" Influenza Virus Vaccine?: Potential Target Antigens and Critical Aspects for a Universal Influenza Vaccine Florian Krammer, Adolfo García-Sastre and Peter Palese

For additional articles in this collection, see http://cshperspectives.cshlp.org/cgi/collection/

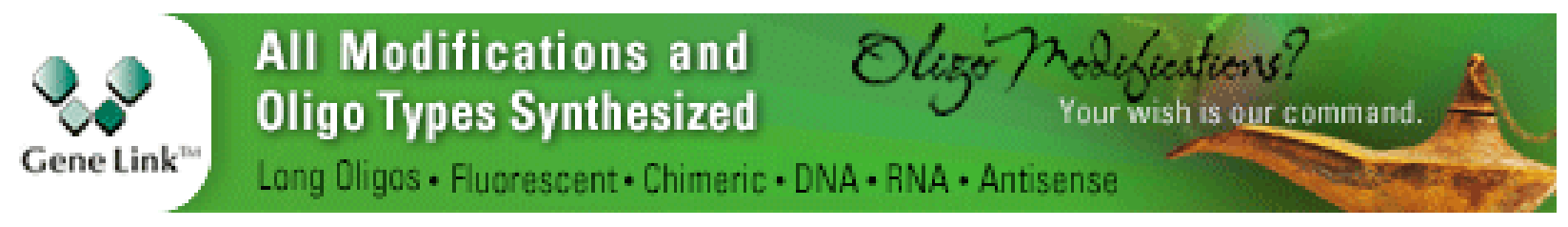

Copyright @ 2018 Cold Spring Harbor Laboratory Press; all rights reserved 